\title{
Pengaruh Kepercayaan Diri Seorang Public relation dalam Berkomunikasi
}

\author{
Chyntania Chantika Triana ${ }^{1}$, Anita Yulianti ${ }^{2}$, Lisna Azka Nuraeni ${ }^{3}$, Adillah Siti Sayyidah ${ }^{4}$
}

Jurusan IImu Komunikasi, Fakultas IImu komunikasi, Universitas Islam Nusantara

\begin{tabular}{|c|c|}
\hline ARTICLE INFO & ABSTRACT \\
\hline Article history: & \multirow{4}{*}{$\begin{array}{l}\text { This study aims to analyze and understand about the influence of a } \\
\text { public relation's confidence in communicating. Confidence as the initial } \\
\text { part of public relations and public speaking activities in communication, } \\
\text { is very interesting to research, considering that public relations will be } \\
\text { awakened if they have confidence in communication. This study uses a } \\
\text { library method in which activities related to the collection of library data } \\
\text { derived from journals, books, and also trusted communication websites } \\
\text { related to the influence of confidence of a public relationThe results } \\
\text { showed that the influence of confidence of a public relation in } \\
\text { communicating can be overcome by increasing confidence by having a } \\
\text { strong and able to put yourself in all situations. The confidence of a } \\
\text { public relations officer is very important because, from that confidence, } \\
\text { we can know and easily carry out a communication, both for the public } \\
\text { and for ourselve. }\end{array}$} \\
\hline $\begin{array}{r}\text { Received Jan 02, } 2022 \\
\text { Revised Feb 09, } 2022 \\
\text { Accepted Maret 01, } 2022\end{array}$ & \\
\hline \multirow{4}{*}{$\begin{array}{r}\text { Keywords: } \\
\text { Kepercayaan Diri; } \\
\text { Public relation; } \\
\text { Berkomunikasi. }\end{array}$} & \\
\hline & \\
\hline & ABSTRAK \\
\hline & $\begin{array}{l}\text { Penelitian ini bertujuan untuk menganalisis dan memahami tentang } \\
\text { pengaruh kepercayaan diri seorang public relation dalam } \\
\text { berkomunikasi. Kepercayaan diri sebagai bagian awal dari public } \\
\text { relation dan kegiatan public speaking dalam komunikasi, sangat } \\
\text { menarik untuk diteliti, mengingat bahwa public relation akan terbangun } \\
\text { apabila mempunyai kepercayaan diri dalam komunikasi. Penelitian ini } \\
\text { menggunakan metode kepustakaan dimana kegiatan yang berkenaaan } \\
\text { dengan pengumpulan data pustaka yang berasal dari jurnal, buku, dan } \\
\text { juga website komunikasi terpercaya yang berkaitan dengan pengaruh } \\
\text { Kepercayaan diri seorang public relation. Hasil penelitian menunjukan } \\
\text { bahwa pengaruh kepercayaan diri seorang public relation dalam } \\
\text { berkomunikasi dapat diatasi dengan meningkatkan kepercayaan diri } \\
\text { yaitu dengan memiliki kemuan yang kuat dan mampu menempatkan diri } \\
\text { dalam segala situasi. kepercayaan diri seorang public relation itu } \\
\text { sangan berpengaruh penting karna, dari percaya diri itu kita bisa } \\
\text { dengan tau dan mudah melakukan sebuah komunikasi baik itu untuk } \\
\text { public ataupun untuk diri sendiri. }\end{array}$ \\
\hline
\end{tabular}

\section{Corresponding Author:}

Chyntania Chantika Triana,

Jurusan IImu Komunikasi, Fakultas IImu komunikasi,

Universitas Islam Nusantara, Jawa Barat, Indonesia

Jl. Soekarno-Hatta No.530, Kota Bandung, Jawa Barat 40286

Email: chyntanialbs@gmail.com

\section{PENDAHULUAN}

Public relation (PR) adalah pekerjaan (umumnya atau kebanyakan untuk sebuah perusahaan) yang mengutamakan komunikasi dari berbagai jenis lisan maupun tulisan. Kegiatan humas pada hakikatnya adalah kegiatan berkomunikasi dengan berbagai macam simbol komunikasi, verbal maupun nonverbal. Kegiatan komunikasi nonverbal sebagian besar adalah pekerjaan menulis 
proposal, artikel, progress report, menulis untuk presentasi, menulis untuk press, membuat rekomendasi, penyelenggaraan pameran, seminar, special event, riset / penelitian, pers kliping, dan lain sebagainya. Sedangkan verbal lisan antara lain jumpa pers, open house, announcer, presenter, desk information, dan lain sebagainya.

Berbicara mengenai Public relation pasti tidak akan jauh dari Public Speaking. Lalu apa itu Public Speaking? Mengapa itu sangat penting untuk seorang Public Relation? Menurut (Putri, 2018) Public speaking merupakan proses berbicara di depan umum atau khalayak untuk menyampaikan informasi, menghibur, dan mempengaruhi audience. Public Speaking adalah kemampuan seseorang untuk berbicara di depan umum dengan benar sehingga pesan dapat dengan jelas tersampaikan dan tujuan berbicara dapat langsung didapatkan (Dunar,2015:16 dalam Putri, 2018). Mengapa Public Speaking itu sangat penting? Bagi sebagian orang hal ini bukan lah sesuatu yang penting, namun berbeda halnya bagi seorang PR karena Public Speaking adalah hal yang sangat penting bahkan akan berpengaruh pada pekerjaan mereka. Seorang Public relation harus mampu menguasai Public Speaking karena dengan kemampuan itu akan memudahkan Public relation membangun citra diri dan perusahaan dengan baik sehingga akan lebih mudah mendapat kepercayaan masyarakat maupun relasi dari perusahaan.

Kepercayaan diri merupakan suatu keyakinan yang dimiliki seseorang bahwa dirinya mampu berperilaku seperti yang dibutuhkan untuk memperoleh hasil seperti yang diharapkan (Bandura, 1977). Rakhmat (1986) mengatakan bila orang merasa rendah diri, ia akan mengalami kesulitan untuk mengkomunikasikan gagasannya pada orang yang dihormatinya dan takut berbicara didepan umum karena takut orang lain menyalahkannya. Lauster (2002) dalam Ardiyana, Akbar, \& Karnadi (2019) menambahkan bahwa orang yang percaya diri memiliki sikap peduli dengan orang atau toleransi, mandiri, dan menjadi diri sendiri. Orang yang percaya diri bukan berarti hanya memahami dirinya sendiri sehingga mengabaikan orang lain melainkan menghargai dan peduli terhadap orang lain.

Komunikasi merupakan kebutuhan manusia yang sangat penting, karena merupakan satusatunya cara bagi manusia untuk bisa mengenal dirinya dan dunia di luar dirinya (Taylor dkk 1986). Komunikasi adalah proses penyampaian suatu pesan oleh seseorang kepada orang lain untuk memberi tahu atau untuk mengubah sikap, pendapat, dan perilaku, baik langsung (komunikasi tatap muka) maupun tidak langsung (komunikasi melalui media) (Nurhadi; 2017). Selain kemampuan berkomunikasi / publik speaking yang harus dimiliki oleh publik Relation, seorang publik relation juga harus memiliki kepercayaan diri dalam menjalani tugasnya dan Kepercayaan diri merupakan sesuatu hal yang harus dipersiapkan dalam diri Seseorang, Karena kepercayaan diri merupakan modal dasar bagi keberhasilan Seseorang di segala bidang.

Dalam public speaking kita sangat memerlukan yang dinamakan percaya diri. Percaya diri dapat mempengaruhi banyak hal dalam berkomunikasi. Percaya diri adalah kunci utama menjadi Public relation yang profesional. Maka dari itu, percaya diri sangat berpengaruhi untuk seorang public relation dalam berkomunikasi. Karena selain percaya diri, public relation juga harus bisa dipercaya oleh publik, sebuah kepercayaan publik tergantung dengan bagaimana public relation dalam berkomunikasi.

\section{METODE PENELITIAN}

Metode penelitian kepustakaan menurut Zed adalah serangkaian kegiatan yang berkenaan dengan pengumpulan data pustaka, membaca, dan mencatat serta mengelola setiap bahan penelitian. Jadi studi kepustakaan dapat dilakukan dengan cara menggunakan jurnal komunikasi, public relation, dan studi kepercayaan diri yang dapat digunakan untuk diteliti dan dapat menghasilkan sebuah karya ilmiah (Gulo, P. 2020)

\section{HASIL DAN PEMBAHASAN}

Pengaruh Kepercayaan Diri Seorang Public Relation, Kepercayaan diri adalah salah satu aspek kepribadian yang penting pada seseorang. Kepercayaan diri merupakan atribut yang sangat berharga pada diri seseorang dalam kehidupan masyarakat, tanpa adanya kepercayaan diri akan menimbulkan banyak masalah pada diri seseorang. Hal tersebut dikarenakan dengan kepercayaan diri, seseorang mampu mengaktualisasi segala potensinya. Kepercayaan diri merupakan sesuatu 
yang urgent untuk dimiliki setiap individu. Kepercayaan diri diperlukan baik olek seorang anak, ataupun orang tua, secara individual maupun kelompok (Afadil, N. 2021).

Kepercayaan diri menurut Oxford Advanced Learner's Dictionary mendefinisikan kepercayaan diri merupakan kemampuan sendiri untuk sesuatu dan dapat berhasil dengan baik. Pendapat yang serupa juga menurut Goleman menyatakan bahwa kepercayaan diri adalah kesadaran yang kuat tentang harga dan kemampuan diri sendiri. Jadi kepercayaan diri adalah kapasilitas seseorang untuk mencapai keberhasilan yang baik dimasa yang akan datang, dan dapat menyadari setiap bakat yang ada dalam dirinya. Sedangkan menurut Rakhmat kepercayaan diri atau keyakinan diri, di artikan sebagai kepercayaan terhadap diri sendiri yang dimiliki setiap individu, dan individu tersebut dapat memandang dirinya secara utuh dengan mengacu pada konsep diri sendiri (Gulo, P. 2020)

Adanya rasa kepercayaan diri membawa pengaruh baik dimana seseorang menjadi tidak mudah dipengaruhi oleh orang lain, mereka yang lebih memilih percaya pada diri dan mampunya tersebut maka tidak akan mudah pula menggoyahkan pilihan yang sudah dipilihnya. Sikap percaya diri ini dapat diasah atau dibentuk melalui pembiasaan hingga peniruan yang didapatkan dari perkataan dan perbuatan baik diri sendiri maupun orang lain. Lingkungan adalah contoh mudah untuk mendapatkan kepercayaan diri, kenyataannya dapat kita lihat dan rasakan melalui pengindraan diri yakni visual, auditori, maupun kinestetik (Hanifa, I. M. 2020).

Kepercayaan diri sangat dibutukan oleh sesorang untuk mengoptimalkan setiap potensi yang dimiliki individu, kepercayaan diri merupakan sikap perasaan yang meyakinkan dengan kemampuan diri sendiri sehingga individu tidak memiliki kecamasan untuk melakukan hal-hal yang disukainya dan memiliki interasi yang baik dengan orang lain. Menurut Surya, kepercayaan diri adalah keyakinan individu terhadap segala aspek yang dimilikinya dan diwujudkan dalam tingkah lakunya sehari-hari serta bagaimana ia menilai diri sendiri dan lingkungan secara positif (Gulo, P. 2020)

Oleh karena itu dapat disimpulkan bahwa kepercayaan diri merupakan hal yang harus dimiliki setiap individu, karena kepercayaan diri menjadikan individu yakin akan kemapuan atau potensi yang ada pada dirinya serta tidak mudah dipengaruhi oleh orang lain. Kepercayaan diri juga dipengaruhi oleh banyak faktor, diantaranya faktor lingkungan, pengalaman dan pola asuh orang tua. Jadi kepercayaan diri individu dapat ditingkatkan dengan pengalaman yang dialami sehari-hari.

Public relations adalah falsafah dan fungsi manajemen yang diekspresikan melalui kebijaksanaan dan kegiatan-kegiatan untuk melayani kepentingan publik, melakukan kegiatan komunikasi bagi publiknya untuk menciptakan pengertian dan goodwill dari publiknya. Dengan demikian pengertian public relations jika dilihat dan diterjemahkan dari asal katanya adalah "Hubungan hubungan antar Publik" atau singkatnya "Hubungan-hubungan publik" (Arkian, M. R. N., Drajat, M. S., \& Ahmadi, D. (2018).

Public relation pada hakikatnya suatu kegiatan yang pasti dilakukan oleh setiap lembaga, baik lembaga pemerintah, lembaga sosial, lembaga pendidikan maupun lembaga perusahaan. Hal ini terjadi karena dalam kehidupan manusia selain sebagai makhluk individu juga sebagai makhluk sosial. Dimanapun manusia berada akan selalu berhubungan dengan masyarakat, baik masyarakat sekitar maupun masyarakat luas. Hubungan yang terjalin dengan masyarakat ditujukan untuk memperoleh keuntungan dan kemudahan bagi kedua belah pihak. Secara sederhana peran dari public relations adalah meng-handle hubungan antara organisasi dengan publiknya (A. R., Darmawan, A., \& Romadhan, M. I., 2019)

Public relation yang sering kita artikan dengan hubungan masyarakat, mempunyai posisi yang sangat urgen dalam suatu organisasi. Sebagai salah satu bagian dari organisasi, public relation yang bertugas dalam berintraksi dengan masyarakat. Masyarakat adalah suatu kesatuan yang didasarkan pada ikatan-ikatan yang telah teratur dan boleh dikatakan stabil (Baharun \& Awwaliyah, 2017 : 225). Eksistensi Public relation dalam suatu lembaga atau instansi merupakan jembatan (mediasi) penyambung antara lembaga dan publiknya. Perkembangan Public relation bertujuan untuk tiap-tiap organisasi dalam publik perlu mendesain hubungannya dengan berbagai elemen masyarakat, agar tercapai hubungan yang serasi dan harmonis (Afkarina, N. I. 2018).

Kemampuan untuk berbicara didepan umum atau yang lebih sering disebut dengan public speaking merupakan kemampuan yang wajib dimiliki oleh seorang public relation. Fungsi public 
relations menjadi sangat penting dan berpengaruh pada keberhasilan maupun kegagalan sebuah organisasi atau perusahaan. Maksudnya kegagalan adalah tidak terciptanya komunikasi dan hubungan baik antara organisasi atau perusahaan kepada publiknya (tidak tercipta pengertian dan dukungan publik). Tidak terciptanya komunikasi dan hubungan yang baik antara organisasi atau perusahaan kepada publiknya bisa berdampak ketidakpercayaan publik terhadap organisasi atau perusahaan serta dampak yang lebih jauh lagi yaitu citra perusahaan dipandang negatif. Maka dari itu, peran seorang public relation sangat penting bagi sebuah perusahaan.

Seorang public relation yang baik harus memiliki sifat percaya diri. Kegiatan yang dilakukan oleh seorang public relation erat kaitannya dengan berkomunikasi dan juga public speaking. Seorang public relation harus bisa tampil percaya diri dalam melakukan komunikasi dan public speaking, karena dirinyalah yang mempunyai pengaruh besar pada keberhasilan maupun kegagalan sebuah organisasi atau perusahaan. Dengan percaya diri berkomunikasi akan lebih efektif melalui gerakan seperti senyum lebar dan meyakinkan. Bahkan jika dalam kondisi mendesak seorang public relation tidak akan menunjukkan bahwa dirinya sedang panik dalam tingkah laku dan nada bicara serta efisiensi dalam berkomunikasi.

Pengaruh kepercayaan diri terhadap seorang public relaitan merupakan alat komunikasi yang digunakan oleh sesama, maka dari itu seorang public relation memegang peran penting dalam komunikasi dan kepercayaan diri terhadap kemampuan berbicaranya. Seperti harus selalau berani dalam memulai komunikasi, pengetahuan yang luas, megetahui cara bekomunikasi massa, menguasai Bahasa yang lancer, mampu berlatih dengan baik dan memiliki rasa percaya diri yang baik (Rini, 2019)

Jadi dapat dikatakan bahwa untuk menjadi public relation harus mempunyai kepercayaan diri yang cukup besar sebagai hal mendasar selain cakap dalam berkomunikasi untuk meningkatkan kepercayaan diri yaitu dengan memiliki kemauan yang kuat dan mampu menempatkan diri dalam segala situasi, dapat berpikir positif dan mempunyai keyakinan yang kuat untuk berhasil, memiliki sikap optimis, dan dapat menyelesaikan tugas secara mandiri.

Faktor yang mempengaruhi terbentuknya kepercayaan diri seorang public relation. Faktor internal yaitu yang berasal dari dalam diri seseorang seperti konsep diri, harga diri, pengalaman hidup dan faktor eksternal yaitu yang berasal dari luar diri seseorang seperti pendidikan, pekerjaan, lingkungan dan masyarakat. Kepercayaan diri bagi seorang public relation sangat penting dalam membantu kelancaran tugas pimpinan dan menunjang prestasi kerja dan berbanding lurus dengan produktivitas perusahaan. contohnya: bertemu dengan klien, bertemu dengan relasi pimpinan.

Public relation dalam Berkomunikasi, Komunikasi merupakan sebuah kajian ilmiah yang dikembangkan sebagai upaya penanaman nilai-nilai dalam pembentukan budaya organisasi (Ritonga, 2020). Komunikasi adalah suatu proses sosial, yang terdiri dari beberapa unit tindakan komunikasi. Dari pemikiran tersebut, West \& Turner, (2007); Wood, (2010); Mukhtar, (2020) menjelaskan lima elemen komunikasi efektif, yaitu sosial, proses, symbol, makna, dan sumber daya. Amrullah (2019) menjelaskan setidaknya ada 5 elemen penting yang terdapat dalam komunikasi, diantaranya adalah: 1) Komunikator: orang yang menyampaikan pesan; 2) Pesan: ide atau informasi yang disampaikan; 3) Media: sarana komunikasi; 4) Komunikan: audience, pihak yang menerima pesan; 5) Umpan balik: respon dari komunikan terhadap pesan yang diterimanya.

Seni berkomunikasi yang efektif dan berhasil dapat dipelajari dan dilatih oleh semua orang. Modal yang diperlukan adalah kerja keras serta teknik yang tepat. Terdapat empat indikator untuk mengetahui efektifitas komunikasi yakni menghasilkan pengertian atau pemahaman, menghasilkan kepuasan atau hiburan, menghasilkan pengaruh pada sikap, dan menghasilkan hubungan yang lebih baik lagi (Adha, 2016).

Komunikasi menyentuh segala aspek kehidupan manusia. Setiap orang yang hidup dalam masyarakat, sejak bangun tidur sampai tidur kembali, secara kodrati senantiasa terlibat dalam komunikasi. Dalam sebuah penelitian diungkapkan, $50 \%$ hingga $70 \%$ waktu bangun manusia digunakan untuk berkomunikasi. Sehingga komunikasi menjadi penentu kualitas hidup manusia (Wok, dkk, 2016). Menurut Muhibudin Wijaya Laksana (2015: 91-101), teori yang komunikasi yang dibutuhkan 4 teori diantarnaya 1) teori tenda. Teori memiliki perinsip pesan memiliki kedudukan yang sangat penting dalam komunikasi dan bagi seorang Public relations itu sangat penting karena merupakan kegiatan menyampaikan pesan. 2) teori hubungan. Teori ini berkaitan dengan 
kepentingan Public relations dalam melakukan komunikasi intrapersonal yaitu dengan berbicara face to face dan memberi kesan yang baik dalam hubunganya dengan orang lain sehingga kesan positif yang diberikan orang terhadap soerang public relations akan mempengaruhi kesan orang terhadap organisasi. 3) teori perubahan sikap. Teori menjelaskan perubahan sikap seseorang dan cara sikap itu dapat berubah melalui sebuah peroses komunikasi dan sikap itu dapat mempengaruhi sikap atau tidaknya tingkah laku seseorang. 4) teori penggunaan dan pemuasan. Teori ini berasumsi bahwa pengguna mempunyai pilihan untuk memuaskan kebutuhanya. Dan yang terakhir 5) teori opini public. Teori ini merupakan teori opini public sebagai masyarakat pada umumnya, integrasi pendapat secara over all atau keseluruhan.

Oleh karena itu Hubungan yang baik ini terjadi karena adanya komunikasi yang baik (public relationship). Dari situlah terbentuk citra perusahaan (corporate image) dimata pihak luar. Hal ini tentunya sesuai dengan defenisi public relations berdasarkan tujuan kegiatannya, yaitu humas sebagai aktivitas berkelanjutan untuk menjamin perusahaan memiliki citra yang kuat dimata publik. (Ritonga \& Hasibuan, 2016).

Komunikasi tidak dapat lepas dengan kegiatan public realations karna public relations membutuhkan komunikasi untuk menunjang kegiatanya. Public relations membutuhkan komunikasi saat melakukan kegiatanya. Karena pada dasarnya Public relations menjunjung tinggi terhadap feed back yang disampaikan publik. Citra seorang Public relations dalam berkomunikasi tidak lepas dari berbagai sesorang tersebut mampu berkomunikasi dengan baik kepada publiknya termasuk memberi respon yang baik kepada publik (Rumsari, 2016).

Public relation juga berfungsi sebagai jembatan untuk membangun suasana yang kondusif dalam kerangka win-win solution, antar berbagai stakeholer organisasi, baik internal maupun eksternal (Syahputra, Hendra, \& Hidayat, 2018). Secara garis besar, public relations merupakan ujung tombak organisasi yang harus terus didesain dan dikembangkan sesuai dengan perkembangan zaman (Agus \& Ummah, 2019), mengingat public relation berfungsi sebagai media komunikasi dengan para pemangku kepentingan untuk menginformasikan visi, misi, tujuan dan program lembaga kepada publik (Afkarina, 2018). Selain berkomunikasi public relation juga harus mempunyai kecakapan dalam hal public speaking untuk menunjang kinerja serta untuk membrading public relation dalam suatu perusahaan atau organisasi. Menurut Fraleigh \& Tuman (2017) public speaking adalah komunikasi antara pembicara dan audiens. Dalam komunikasi di depan umum biasanya pembiacara melakukan aktivitas verbal (berbicara), sedangkan audiens hanya mendengarkan namun tidak bersikap pasif, artinya audiens dapat merespon apa yang didengarnya.

Public speaking yang dikemukakan oleh Juddy Pearson dan Paul Nelson (dalam Srisadono, 2018) mereka mendefinisikan bahwa public speaking sebagai proses menggunakan pesan untuk menimbulkan kesamaan makna dalam sebuah situasi dimana sumber mentrasmisikan pesan kesejumlah penerima yang kemudian memberikan unpan balik berupa pesan atau komunikasi nonverbal maupun berupa Tanya jawab.

Menurut Bahar, public speaking bukan hanya sekedar kemampuan berbicara didepan audiens yang banyak, akan tetapi bagaimana dapat berbicara dengan cara yang menarik, informatif, dapat mempengaruhi pendengarnya, dan menghibur (dalam Oktavianti, 2019). Dannis L. Wilcox (dalam Soeparan 2020) menyatakan bahwa public speaking adalah salam satu proses komunikasi yang berkelanjutan yang dimana pesan dan lambang bersikulasi berulang-ulang secara terus menerus antara pembicara dan audiensnya, namun secara umun dalam masyarakat orang -orang memahami bahwa public relation adalah kemampuan berbicara di depan umum yang merupakan sebuah keterampilan. Dalam kegiatan ini biasanya berdasar dari sebuah latihan, pengakaman berbicara dan praktek berbicara di depan orang banyak

Dengan demikian public relation sangat bergantung kepada komunikasi, karena tugas mereka sangat membutuhkan adanya komunikasi dimana public relation menjembatani permasalahan antara kedua belah pihak yang pastinya membutuhkan komunikasi agar masalah tersebut dapat terselesaikan dengan baik. Public relation juga bertugas untuk memberikan informasi dan juga menerima informasi, dimana saling memberi atau menerima informasi merupakan bentuk dari komunikasi.

Selain itu public relation juga harus memiliki kecakapan dalam public speaking, karena public speaking adalah hal yang sangat penting bahkan akan berpengaruh pada pekerjaan public 
relation Seorang public speaking harus mampu menguasai Public Speaking karena dengan kemampuan itu akan memudahkan public relation membangun citra diri dan perusahaan atau oraganisasi dengan baik sehingga akan lebih mudah mendapat kepercayaan masyarakat maupun relasi dari perusahaan. Jadi seorang public relation akan dikatakan profesional apabila dia menguasai Public Speaking, mampu untuk membangun komunikasi yang baik dengan masyarakat di sekitar perusaahan, karyawan dalam perusahaan, dan juga relasi yang bekerja sama dengan perusaahan. Selain itu, Public speaking juga mengajarkan kita untuk menjadi seorang pemimpin dengan percaya diri dan berfikir kritis.

\section{KESIMPULAN}

Kepercayaan diri merupakan atribut yang sangat berharga pada diri seseorang dalam kehidupan masyarakat, tanpa adanya kepercayaan diri akan menimbulkan banyak masalah pada diri seseorang Kepercayaan diri sangat dibutukan oleh sesorang untuk mengoptimalkan setiap potensi yang dimiliki individu, kepercayaan diri merupakan sikap perasaan yang meyakinkan dengan kemampuan diri sendiri sehingga individu tidak memiliki kecamasan untuk melakukan hal-hal yang disukainya dan memiliki interasi yang baik dengan orang lain. Maka dari itu kepercayaan diri dalam seorang public relation sangatlah penting karena dalam kepercayaan diri tersebut seorang public relation bisa menjalankan tugasnya dengan baik. Komunikasi bukan suatu hal yang mudah untuk dilakukan, maka dengan itu public relation yang pekerjaannya berkaitan dengan komunikasi sangat membutuhkan kepercayaan yang tinggi dalam melakukannya. Karena public relation bertugas dalam memberikan informasi atau juga menerima informasi baik bagi individu dengan individu, individu dengan publik, publik dengan individu, atau publik dengan publik., dimana hal ini membutuhkan komunikasi agar mendapatkan solusi bersama. Komunikasi juga menjadi salah satu proses tercapainya kepercayaan diri dalam seseorang, di ibaratkan bila kita tidak mempunyai sebuah komunikasi yang baik kita akan sangat tidak percaya diri dan sulit untuk berkomunikasi dengan sekitar sehingga hanya akan mendapatkan miss komunikasi dan bisa menjadi sebuah nois saat kita berkomunikasi tanpa adanya percaya diri. Maka dari itu kepercayaan diri seorang public relations itu sangan berpengaruh penting karna, dari percaya diri itu kita bisa dengan tau dan mudah melakukan sebuah komunikasi baik itu untuk public ataupun untuk diri sendiri.

\section{Referensi}

Afadil, N. (2021). KEPERCAYAAN DIRI REMAJA ANAK TKI (Studi Kasus di Desa Semanding Kecamatan Jenangan) (Doctoral dissertation, IAIN Ponorogo).

Afkarina, N. I. (2018). Strategi komunikasi humas dalam membentuk public opinion lembaga pendidikan. Jurnal Idaarah, 2(1), 50-63.

Agatha, J. S., \& Oktavianti, R. (2020). Tindakan Bullying dalam Komunikasi Antarpribadi Semasa SMA dan Dampaknya pada Nilai Public Speaking dan IPK. Koneksi, 4(2), 251-257.

Amalia, V. (2020). Strategi Komunikasi Humas Dalam Meningkatkan Public Trust Di Perguruan Tinggi (Studi Kasus Di Universitas Nurul Jadid, Paiton, Probolinggo). AL-TANZIM: Jurnal Manajemen Pendidikan Islam, 4(1), 13-23.

Ardiyana, R. D., Akbar, Z., \& Karnadi, K. (2019). Pengaruh Keterlibatan Orang Tua dan Motivasi Intrinsik dengan Kepercayaan Diri Anak Usia Dini. Jurnal Obsesi: Jurnal Pendidikan Anak Usia Dini, 3(2), 494-505.

Arkian, M. R. N., Drajat, M. S., \& Ahmadi, D. (2018). Peran Public Relations dalam Film Hancock. Inter Komunika, 3(2), 145-152.

Bandura, A., 1977, Social Learning Theory, New Jersey: Prentice Hall Inc.

Dewi, S. A. E. (2021). Komunikasi Publik Terkait Vaksinasi Covid 19. HEALTH CARE: JURNAL KESEHATAN, $10(1), 162-167$.

Gulo, P. B. V. (2020). Studi Meningkatkan Kepercayaan Diri Anak Untuk Memimpin.

Hanifa, I. M. (2020). STUDI LITERATUR PADA KEPERCAYAAN DIRI INDIVIDU TERKAIT MOTIVASI UNTUK MENINGKATKAN KUALITAS BELAJAR.

Ismaulidina, I., Hasibuan, E. J., \& Hidayat, T. W. H. W. (2020). Strategi Komunikasi Public relation Dalam Membangun Citra Dan Kepercayaan Calon Jemaah Haji dan Umroh. Jurnal Ilmu Pemerintahan, Administrasi Publik, dan IImu Komunikasi (JIPIKOM), 2(1), 12-17.

Junita, J., Zainuddin, Z., Hajar, I., Muti'ah, R., \& Siregar, M. Efektivitas Prinsip Komunikasi Islam Guru dalam Pembinaan Karakter Komunikasi Siswa Kelas X MAN Rantauprapat. JUPIIS: JURNAL PENDIDIKAN ILMU-ILMU SOSIAL, 13(1), 78-88.

Mukarom, Zainal dan Muhibudin Wijaya Laksana. 2015. Manajemen Public Relations, Panduan Efektif Pengelolaan Hubungan Masyarakat, Bandung: Pustaka Setia.

Nurhadi, Z. F. (2017). Model komunikasi sosial remaja melalui media twitter. Jurnal Aspikom, 3(3), 539-549. 
Nursanti, S., Utamidewi, W., \& Tayo, Y. (2021). Kualitas Komunikasi Keluarga tenaga kesehatan dimasa Pandemic Covid-19. Jurnal Studi Komunikasi, 5(1), 233-248.

Oktavianti, R., \& Rusdi, F. (2019). Belajar Public Speaking sebagai Komunikasi yang Efektif. Jurnal Bakti Masyarakat Indonesia, 2(1).

Prasetyo, M. A. M., \& Anwar, K. (2021). Karakteristik Komunikasi Interpersonal serta Relevansinya dengan Kepemimpinan Transformasional. Jurnal Komunikasi Pendidikan, 5(1), 25-39.

Putri, E. A. (2018) Pentingnya Keterampilan Public Speaking Bagi Sekretaris Tugas Akhir diakses pada 14 Desember2020, http://staffnew.uny.ac.id/upload/132310864/pendidikan/TUGAS\%20AKHIR\%20EKWINA.pdf

Rakhmat,J., 1986, Psikologi Komunikasi, Bandung: Remaja Karya

Rini, S. (2019) 6 Penyebab Konflik Peran Ganda Dalam Psikologi. Diakses pada tanggal 4 Juli 2021 dari https://dosenpsikologi.com/penyebab-konflik-peran-ganda-dalam-psikologi

Soeparan, P. F. (2020). Penguasaan Public Speaking Yang Baik Dalam Rangka Melatih Kemampuan Berbicara Di Depan Umum. Jurnal Pengabdian Kepada Masyarakat (JUDIKA), 1(1), 35-42.

Sumarto, R. H. (2016). Komunikasi Dalam Kegiatan Public Relations. Informasi, 46(1), 63-72.

Syahputra, D. I., Hendra, Y., \& Hidayat, T. W. (2018). Peran Humas Dalam Membangun Citra Pemerintahan Sumatera Utara Pada Kantor Biro Humas Gubernur. PERSPEKTIF, 7(1), 24-29.

Tamelab, P., Ngongo, M. H. L., \& Oetpah, D. (2021). MENINGKATKAN KEPERCAYAAN DIRI MAHASISWA DALAM KEMAMPUAN PUBLIC SPEAKING DI SEKOLAH TINGGI PASTORAL KEUSKUPAN AGUNG KUPANG. Selidik (Jurnal Seputar Penelitian Pendidikan Keagamaan), 2(1), 54-63.

Windriati, A. R., Darmawan, A., \& Romadhan, M. I. (2019). Peran public relations dalam membangun citra di Atlantis Land Surabaya. Jurnal Representamen, 5(1). 